\title{
PENSAMENTO AMERÍNDIO: COSMOPOLÍTICA CONTRA O ETNOCÍDIO
}

\author{
Gustavo Fontes ${ }^{1}$ \\ Universidade Federal do Paraná (UFPR) \\ (D) https://orcid.org/0000-0002-9194-8619
}

\section{RESUMO:}

Neste texto propõe-se primeiramente uma definição do conceito de Cosmopolítica, alertando para suas implicações filosóficas e epistêmicas, e em seguida empreende-se uma problematização da relação do pensamento ocidental com o pensamento ameríndio, a partir de alguns marcos históricos, jurídicos, teorias antropológicas e filosóficas; afim de construir uma janela para se pensar a densidade desta relação, índios e não-índios, na contemporaneidade.

PALAVRAS CHAVE: Pensamento ameríndio; Cosmopolítica; Etnocídio.

\section{AMERINDIAN THOUGHT: COSMOPOLITICS AGAINST ETHNOCIDE}

\begin{abstract}
:
This text proposes, first of all, a definition of the concept of Cosmopolitics, alerting to its philosophical and epistemic implications, and then we undertake a problematization of the relation of Western thought with Amerindian thought from some historical, juridical, anthropological and philosophical milestones; in order to construct a window to think the density of this relation between Indians and non-Indians in contemporaneity.
\end{abstract}

KEYWORDS: Amerindian thought; Cosmopolitics; Ethnocide.

\footnotetext{
${ }^{1}$ Mestre em Filosofia pela Universidade Federal do Paraná (UFPR), Brasil. Pesquisador do SPECIES, Núcleo de antropologia especulativa. E-mail: fontesholanda@gmail.com

Pensamento ameríndio: cosmopolítica contra o etnocídio - Gustavo Fontes

Griot : Revista de Filosofia, Amargosa, Bahia - Brasil, v.15, n.1,p.391-417, junho/2017 
Isabelle Stengers em seu artigo La propuesta Cosmopolítica (2014), define o termo cosmopolítica como sendo uma bandeira de alerta, uma forma de não submergirmos a lógica dominante que pensa o lugar genuíno da política como o espaço transcendente a partir do qual é possível julgar: "el régimen usual de pensamiento es la trascendencia, que autoriza posición y juicio" (STENGERS, 2014, p. 35). A partir dessa constatação, a proposta Cosmopolítica se dispõe a pensar os limites, as circunscrições cósmicas, os regimes de imanência, para finalmente, a partir deste reconhecimento, propor convergências possíveis, as quais operariam sob o signo da igualdade, mas não da equivalência, e sobretudo, impossíveis de serem subsumidas em nome do projeto ocidental da razão transcendente.

Segundo a autora:

el cosmos, tal como figura en el término cosmopolítica, designa lo desconocido de estos mundos múltiples, divergentes; las articulaciones de las que podrían llegar a ser capaces, contra la tentación de una paz que se quisiera final, ecuménica, en el sentido en que una trascendencia tendría el poder de exigirle a lo que diverge que se reconozca como una expresión meramente particular de lo que constituye el punto de convergencia de todos (STENGERS, 2014, p. 22).

Neste sentido, entendemos que Cosmopolítica se propõe como um enfrentamento da unificação do mundo feita pela ciência moderna (mas também, e sobretudo, pela política que lhe subjaz) propondo algo particularmente difícil e desafiador para a tradição da razão ocidental: a humildade, no que se refere a disposição de que talvez não conheçamos todos os mundos possíveis que existem de fato. E isto não por falta de ferramentas, métodos, profundidade ou rigor na investigação ontológica; mas principalmente por que estes mundos são agenciados por humanos outros [e outros que humanos].

Sendo assim, a proposta Cosmopolítica não pode ser confundida com o primeiro sentido que recebeu da tese kantiana da paz universal, aquela que se propunha como o lugar ideal da razão transcendente, de onde tudo que diverge deveria se reconhecer como mera particularidade, variação, exotismo. Naquele projeto a pacificação tinha como pressuposto a imposição de uma identidade e da centralidade de um poder absoluto que se estruturaria a partir da relação mando-obediência. Ou seja, sua dinâmica se dá pela negação da diferença (ontológica) e a imposição de uma hierarquia: este é o horizonte do projeto de uma paz perpétua a partir do cosmopolitismo iluminista, o que, sob todos os aspectos, inviabiliza uma discussão cosmopolítica como a que está aqui proposta.

Esta disposição também exige reconhecermos que mesmo com todas as ferramentas, métodos, conhecimentos, ontologias, não estamos nos saindo muito bem na gestão deste mundo o qual há pelo menos meio milênio estamos empenhados em impor a todos os povos do planeta. Neste 
sentido, a Cosmpopolítica se propõe como uma maneira de participar na criação necessária de um "common sense cosmopolítico, de un espíritu de reconocimiento de la alteridad del otro, capaz de aprehender las tradiciones étnicas, nacionales y religiosas, y de procurar que se beneficien de sus mútuos intercambios" (STENGERS, 2014, p. 40-41).

Por fim, Cosmopolítica no sentido aqui proposto está então relacionada ao reconhecimento do direito político (ao estatuto ontológico ligado ao fato) de outras culturas habitarem outros cosmos que não aquele governado ou mapeado pela ciência moderna. É neste sentido que uma aproximação com a obra do antropólogo e pensador francês Bruno Latour se faz estratégica, para se efetuar uma crítica à unificação do mundo realizada pela ciência moderna.

Latour, em Jamais fomos modernos (1994), afirma que esta unificação do mundo ocorreu a partir da projeção de uma imagem da natureza universal realizada pelos modernos a partir da constatação de que o Ocidente desbravador e expansionista foi vitorioso naquele momento de mapeamento do globo terrestre porque, diferente das outras culturas, não dominava uma imagem ou representação simbólica da natureza, "mas a Natureza, tal como ela é, ou pelo menos tal como ela é conhecida pelas ciências - ciências que permanecem na retaguarda, impossíveis de serem estudadas, jamais estudadas" (LATOUR, 1994, p. 96).

Ou seja, a imagem da natureza projetada pela ciência moderna assume o lugar deixado pelo "Ser" - enquanto impostor da velha metafísica, segundo o filósofo da antropofagia Oswald de Andrade, que se projeta sobre toda a realidade visando sua unificação. E desta problematização surge um questionamento essencial para melhor entendermos as relações de força colocadas em marcha pela modernidade e o status que a ciência aí ocupa: "se os ocidentais houvessem apenas feito comércio ou conquistado, pilhado e escravizado, não seriam muito diferentes dos outros comerciantes e conquistadores. Mas não, inventaram a ciência, esta atividade em tudo distinta da conquista e do comércio, da política e da moral" (LATOUR, 1994, p. 97),

Sendo assim, pensar as lutas cosmopolítica na contemporaneidade implica então realizar (ainda que soe como um sacrilégio para muitos) uma crítica a esta unificação pacificada realizada pela ciência moderna a partir da imagem de uma natureza universal. E para concluirmos provisoriamente esta discussão com a obra latouriana, vejamos esta citação:

Como é possível que alguém não veja uma diferença radical entre a natureza universal e a cultura relativa? Mas a própria noção de cultura é um artefato criado pelo nosso afastamento da natureza. Ora, não existem nem culturas - diferentes ou universais - nem uma natureza universal. Existem apenas naturezas-culturas, as quais constituem a única base para comparações (LATOUR, 1994, p. 102). 
Pois é justamente esta constatação que nos permite pensar o conceito de lutas cosmopolíticas, ou do que o autor vai chamar em outro texto de "guerra de mundos". Afinal, é o conceito ocidental de cultura como algo afastado e oposto a Natureza que sustenta esta imagem de uma natureza universal. Logo, uma outra cultura, como a ameríndia, vivencia e agencia uma outra natureza, e por isso se torna apropriado falar em lutas cosmopolíticas.

Outro autor fundamental para se pensar o contexto cosmopolítico atual, particularmente relacionado ao horizonte ameríndio, é o antropólogo brasileiro Eduardo Viveiros de Castro, pois sua obra nos permite restaurar a ideia de uma diferença cultural radical como uma diferença ontológica $\mathrm{Ou}$ seja, um outro cosmos dentro do qual se opera uma outra política. Segundo ele, o pensamento ameríndio:

\begin{abstract}
reconhece outros modos de existência que o nosso; justifica uma outra prática da vida, e um outro modelo do laço social; distribui diferentemente as potências e as competências do corpo e da alma, do humano e do extra-humano, do geral e do particular, do ordinário e do singular, do fato e do feito; mobiliza, em suma, toda uma outra imagem do pensamento. Alteridade cultural radical (VIVEIROS DE CASTRO, 2011, p. $6)$.
\end{abstract}

Esta declaração nos aproxima muito do propósito de reconhecimento da diferença cultural radical como uma dimensão da experiência de mundo impossível de ser pacificada ou planificada. Apenas, e infelizmente, aniquilada, suprimida ou assimilada.

É neste sentido que Viveiros de Castro entende que é fundamental para seu projeto retomar a linguagem da ontologia para enfrentar "o bloqueio desrealizante desse pensamento [o ameríndio] através de sua redução às dimensões de um conhecer ou representar, isto é, a uma 'epistemologia' ou a uma 'visão de mundo'" (VIVEIROS DE CASTRO, 2001, p. 9). E para isso o autor articula sua teoria antropológica do "perspectivismo amazônico" ou "perspectivismo multinaturalista" com o conceito de "autodeterminação ontológica" (2010, p. 18), para se referir ao que seria a cosmopolítica destes povos. Conclui por fim, que o mundo ameríndio seria, "um mundo metafisicamente antropofágico, onde a alteridade é anterior à identidade, a relação superior aos termos, e a transformação interior à forma" (VIVEIROS DE CASTRO, 2001, p. 6).

Sobre esse ponto, Oswald de Andrade mais uma vez, salienta a importância crítica da obra de Alfred N. Whitehead, ao acenar para sua formulação acerca da importância do "conceito de um mundo lógico, ordenado por um ente supremo para o progresso da Física" (ANDRADE, 1978, p. 97). Ou seja, é este conceito de um mundo lógico, ordenado por um ente supremo cientificamente inominável, que permitiu à ciência moderna a 
unificação pacificada do mundo. De forma que, desde então, não haveria mais "guerra de mundos", já que só haveria um mundo, o mapeado pela ciência moderna e dominado pelo capitalismo. O "resto" seriam apenas projeções, superstições, crenças; em suma, ignorância frente ao princípio.

É esta consideração que permite a Latour afirmar que:

les guerres ne portent jamais sur les mondes, mais seulement sur les représentations symboliques du monde ; l'unité est déjà faite, il suffit que la dose de nature universelle augmente partout et l'accord se fera par simple conséquence ; enfin, comme cette nature universelle n'a pas de sens humain, il est indispensable de conserver les cultures pour embellir, enrichir, ajourer, par des valeurs et des passions, le dur monde des faits et de la raison - à condition bien sûr qu'aucune de ces cultures ne conserve de prétentions ontologiques (LATOUR, 2015, p. $4-5)$.

Para relativizar esta postura tão arraigada no senso comum formado pelo paradigma do progresso científico e tecnológico, seria interessante levantar algumas colocações do também antropólogo, o norte-americano Roy Wagner. As citações que seguem estão presentes em seu livro $A$ invenção da cultura (2012). Uma primeira colocação deste autor, seminal para o debate acerca da evolução da espécie e suas posteriores diferenciações culturais (e/ou ontológicas) é a seguinte: “Tornar-se humano' em nossa tradição é tanto uma tarefa moral para o indivíduo como uma tarefa evolutiva para a espécie, e a decisão de tratar esses dois aspectos como sendo o mesmo conferiu ao nosso estudo das origens do homem suas conotações teleológicas ou moralistas" (WAGNER, 2012, p. 309).

Ou seja, pensar as civilizações ameríndias como pertencendo a um passado da humanidade não passa de um pré-conceito epistemológico, baseado em uma teleologia que coloca a escrita e a formação de Estado como finalidade inexorável de qualquer ajuntamento humano. Um préconceito que não se sustenta se nos detivermos na complexidade do pensamento destes coletivos étnicos e suas sofisticadas técnicas e/ou estratégias de vida em sociedade. No campo da técnica estritamente falando, temos, por exemplo, que a cerâmica mais antiga do continente foi encontrada na região de Santarém, há cerca de 7 mil anos atrás. Isso sem falar na domesticação e manejo de diversas espécies de plantas ${ }^{2}$.

Partindo, portanto, do reconhecimento incontornável da complexidade que rege a vida deste povos, as quais talvez tenham ficado mais evidentes a partir dos trabalhos de Lévi-Strauss e Pierre Clastres: o

${ }^{2}$ Conhecimento este até hoje pirateado pela indústria farmacêutica e estética, vide por exemplo o último escândalo acerca das propriedades adoçantes da Stévia, envolvendo a Coca Cola os Guarany. Cf. matéria da BBC: Como um adoçante virou centro de uma batalha entre indígenas e multinacionais (Dez/2016). 
primeiro se detendo sobre as estruturas elementares do Pensamento selvagem (2008) - parentesco, mitologia e a ciência do concreto; o segundo apresentando as nuances políticas destes coletivos humanos que conseguiram estruturar suas sociabilidades impedindo ou refratando a relação de mando-obediência e seu necessário desdobramento na coerção. Neste sentido: "a ideia de que alguns dos contextos reconhecidos em uma cultura são 'básicos' ou 'primários', ou representam o 'inato', ou de que suas propriedades são de algum modo essencialmente objetivas, é uma ilusão cultural" (WAGNER, 2012, p. 120).

Pois, do ponto de vista histórico, desde que o homem começou a constituir cultura, dominar o fogo e viver em comunidade, tornou-se inviável insistir na ideia de evolução: "o homem, não é menos 'natural' agora, não é menos animal do que já foi. Ele não é mais 'cultural' em seu estado presente do que o foram seus antepassados" (WAGNER, 2012, p. $317)$.

Neste sentido, e para voltarmos ao sentido aqui proposto de cosmopolítica: "uma vez que o pensamento é inseparável da ação e da motivação, não estamos lidando tanto com diferentes 'lógicas' ou racionalidades quanto com modos totais de ser, de inventar o eu e a sociedade" (WAGNER, 2012, p. 276). Poderíamos acrescentar: modos totais de constituir, enfim, um mundo. Logo, ao nos debruçarmos sobre o horizonte do pensamento ameríndio, propomos aqui pensar que estes coletivos humanos, "mais do que oferecer um contraste com a nossa cultura, ou contraexemplo para ela", seria mais interessante e produtivo, pensá-los, "como um sistema total de conceitualização", que nos convida "a uma comparação com 'outros modos' de lidar com "nossa própria realidade" (WAGNER, 2012, p. 328).

E é por isso que se trata fundamentalmente de reconhecer a autodeterminação ontológica destes povos, ou seja, de que eles vivem uma realidade outra, não redutível a nenhum - insisto, nenhum dos nosso paradigmas epistemológicos ocidentais. Nem mesmo ao paradigma científico que propõe a existência de uma realidade objetiva (Natureza) como sendo algo independente de qualquer cultura, pois essa distinção repousa na invenção cultural da "existência de uma ordem fenomênica e inata chamada 'natureza' como algo distinto daquela coisa artificial e aperfeiçoável que chamamos de "cultura"” (WAGNER, 2012, p. 325).

Neste sentido, o empirismo naturalista, que está no cerne de nosso conceito de ciência, a partir, por exemplo, do princípio de eficiência enquanto o "apelo aos 'fatos' naturais e a experiência da natureza como um meio de 'prova' e certeza científica - é então essencialmente um apelo à efetividade de nossos próprios controles culturais". (WAGNER, 2012, p. 327). A ciência, nesta leitura, deixa de ser uma explicação do mundo, para se tornar mais uma das narrativas que legitimam a projeção que os coletivos 
humanos fazem do mundo, a partir da divisão ocidental entre Natureza e Cultura.

Partindo então desta explanação inicial acerca do que se entende aqui por Cosmopolítica, proponho no decorrer deste artigo pontuar alguns aspectos mais marcantes relativos a este encontro [mau-encontro ou guerra de mundos], que vem ocorrendo aqui nas terras baixas da América do Sul há pelo menos meio milênio. Nesta discussão, seguirei alguns apontamento feitos por Pierre Clastres, de quem compartilho a ideia que a força principal responsável pela expansão da guerra de mundos, e do etnocídio que a acompanha, é o Estado Capitalista. Voltaremos a isso mais adiante. Por hora proponho uma breve recapitulação histórica.

\section{A experiência de meio milênio de Fim do Mundo}

Há cerca de quinhentos anos atrás aqui chegaram os europeus com seus vírus e bactérias; seu plano de salvação das almas dos nativos que passava necessariamente pelo etnocídio, e com uma sede insaciável por ouro e riquezas. $\mathrm{O}$ antropólogo e pensador brasileiro Darcy Ribeiro em seu livro As Américas e a civilização (1977), faz uma distinção histórico-política deveras interessante acerca dos interesses que moveram os europeus no que se convencionou chamar de conquista do Novo Mundo.

Segundo sua teoria, a primeira leva de europeus que chegaram as Américas, os que habitavam a Península Ibérica (Portugal e Espanha), por serem os principais celeiros da Igreja Católica, encontravam-se então impulsionados pelo que ele chamou de mercantil-salvacionismo. Ou seja, a principal questão relativa a invasão e conquista era obviamente o mercantilismo enquanto representante oficial dos interesse materiais e monetários, enquanto modelo econômico de negócio e prática política de fortalecimento destes Estados e suas fronteiras. No entanto, o salvacionismo constituía por sua vez parte "capital" dos argumentos da Conquista, pois concernia aos interesses ligados à teoria desenvolvida pela teologia católica, que naquele momento tinha status de razão de Estado. Esta teoria, que postulava a necessidade de salvar as almas daqueles gentios encontrados em estado de perdição e primitivismo, constituía a parte mais elaborada da razão Ocidental enquanto narrativa sobre o que era o mundo e por que sua imagem precisava ser imposta a todos os outros povos do planeta. Darcy Ribeiro assim coloca a questão:

antes do amadurecimento das formações capitalista-mercantis, ocorreu um outro processo civilizatório, o primeiro a proporcionar a ruptura com o feudalismo europeu e a emergência de uma nova formação sócio-cultural: a mercantilsalvacionista. Sua base tecnológica, provida pela Revolução Mercantil, se assentava na navegação oceânica, nas armas de fogo, no ferro forjado e em outros elementos que liquidaram a 
cavalaria de guerra dominante a mais de um século (RIBEIRO, 1977, Pg. 54).

Neste sentido, completa o autor:

A Europa que se defronta com a América Indígena representada pela Espanha e por Portugal era constituída por sociedades nacionais de base agrário-artesanal rigidamente estamentadas. Sua cúpula era formada antes por uma hierarquia sacerdotal do que por uma nobreza hereditária, dada a posição da Igreja como principal proprietária de terras, escravos e servos e da especialização guerreira de uma parte do clero como padres-soldados (RIBEIRO, 1977, p. 57).

Esta questão fica particularmente clara quando nos referimos a uma figura deveras interessante que viveu de maneira ambígua, apaixonada, contraditória e particularmente intensa os eventos relacionados aos primeiro anos de invasão e conquista. Me refiro ao amigo íntimo de Cristóvão Colombo, primeiro sacerdote ordenado no Novo Mundo, Bispo da cidade Real de Chiapas e ferrenho defensor dos povos nativos da América: Bartolomeu de Las Casas.

De sua trajetória, que vai de aventureiro dono de escravos ao mais ferrenho e brilhante defensor da causa indígena ${ }^{3}$, destaca-se o episódio que ficou conhecido como a controvérsia de Valladolid, quando o frei, convocado pelo Imperador Carlos I de Espanha ${ }^{4}$, pai de Felipe II, se viu obrigado refutar os argumentos tradicionais acerca dos direitos dos cristãos sobre os povos descobertos que até então encontravam-se tradicionalmente fundamentados na teoria aristotélica da servidão natural. $\mathrm{O}$ representante da corrente hegemônica neste debate histórico foi o renomado Doutor Juan Jimenes Sepúlveda.

Os argumentos decorrentes da teoria da servidão natural presentes na Política de Aristóteles (1998) encontravam-se amplamente divulgados a parir de dois silogismos muito correntes na época da Conquista. O primeiro: os bárbaros são naturalmente escravos; os índios são bárbaros; logo, os índios são naturalmente escravos. E o segundo: é lícito fazer a guerra contra os naturalmente escravos para subjugá-los; os índios são naturalmente escravos; logo, é lícito fazer a guerra contra os índios para subjugá-los (GUTIERRËZ, 2014, p. 223).

De fato, na discussão que queremos empreender acerca do estatuto político e ontológico das populações ameríndias, do ponto de vista do Ocidente (ou da Filosofia tradicional) Aristóteles é de fato um marco

\footnotetext{
${ }^{3}$ Tão radical quanto poderia ser, neste assunto, um padre naquele contexto histórico.

${ }^{4} \mathrm{O}$ fórum escolhido foi o Consejo Real de Indias, incrementado por uma comissão ad hoc de teólogos, juristas e canonistas. A cidade foi Valladolid. A convocação real foi realizada em 7 de julho de 1550. A junta teve duas sessões: a primeira, em agosto ou setembro de 1550, e a segunda, em abril ou maio de 1551 (Gutiérrez, 2014, p. 228).
} 
incontornável. E é neste sentido que Las Casas se viu obrigado a propor uma nova versão para a leitura canônica de Aristóteles, tributária da Suma Teológica de Tomás de Aquino, afim de enquadrar os nativos ameríndios em um novo paradigma relativo ao direito cristão à vida e ao livre arbítrio.

De um lado tínhamos então a teoria da guerra justa contra os bárbaros formulada da seguinte maneira pelo Dr. Sepúlveda, a qual representava de fato uma síntese excelente das ideias de Aristóteles aplicadas ao ocaso ameríndio:

e é por isso que as feras são domadas e submetidas ao império do homem. Por essa razão, o homem manda na mulher, o adulto na criança, o pai, no filho: isso quer dizer que os mais poderosos e os perfeitos dominam os mais fracos e os mais imperfeitos. Constata-se essa mesma situação entre os homens, pois há os que, por natureza, são senhores e os que, por natureza, são servos. (...). Pois está escrito nos Provérbios: o tolo servirá ao sábio'. Assim são as nações bárbaras e desumanas estranhas a vida civil e aos costumes pacíficos. [...] E sempre será justo e de acordo com o direito natural que essas pessoas sejam submetidas ao império de príncipes e de nações mais cultivadas e humanas, de modo que graças à virtude dos últimos e á prudência de suas leis, eles abandonam a barbárie e se adaptam a uma vida mais humana e ao culto da verdade (SEPÙLVEDA, in LAS CASAS, 1984, p. 23).

O centro da questão encontrava assim na relevância e pertinência da aplicação do conceito de barbárie para se referir aos ameríndios, o qual Las Casas se dispôs a refutar. É digno de nota ainda o fato de que a Espanha se viu obrigada a elaborar uma teoria para a Conquista que estivesse em acordo com as doutrinas do que era então conhecido como os Direitos das Gentes, sendo o respeito a estes princípios o principal critério para que as Conquistas espanholas (cristãs) não fossem confundidas ou equiparadas com a dos Turcos ou Muçulmanos. Ou seja, a Espanha - e também Portugal em alguma medida, foram os únicos Estados a terem escrúpulos de consciência ao empreender a invasão e conquista, coisa que não irá se suceder posteriormente: tanto para a Inglaterra, quanto para Holanda, França, a questão já estava resolvida na prática pelo sucesso militar da Conquista.

Neste ponto seria interessante fazermos uma breve digressão para mencionarmos a teoria de uma primeira modernidade ibérica defendida pelo filósofo argentino Enrique Dussel. Segundo ele, uma das maiores grosserias feitas pela história hegemônica da Filosofia Ocidental foi desconsiderar o impacto intelectual, filosófico e político dos primeiros encontros, em nome da questão meramente econômica acerca dos primeiros séculos da Conquista para a estruturação do que se convencionou chamar de Modernidade. Esta é uma investigação infelizmente ausente dos departamentos de Filosofia brasileiros, mas traz uma questão 
particularmente importante para os interessados em um projeto de emancipação intelectual da América latina, ou simplesmente aos atentos as nuances ideológicas presentes na História da Filosofia.

Basicamente o que Dussel defende é a importância da entrada da América no cenário global das relações econômicas e políticas, e suas consequências filosóficas para o que se vai chamar posteriormente de Modernidade. Segundo ele:

a primeira modernidade hispânica, renascentista e humanista, produziu uma reflexão teórica ou filosófica da maior importância, que passou despercebida para a chamada 'filosofia moderna' (que só é a filosofia da 'segunda modernidade'). O pensamento teórico e filosófico do século XVI tem importância atual porque é o primeiro, e o único, que viveu e exprimiu a experiência originária no tempo da constituição do primeiro "sistema mundo". Por isso, a partir dos recursos teóricos que se tinha (a filosofia escolástica muçulmano-cristã e renascentista humanista) a questão éticofilosófica central foi a seguinte: Que direito tem o europeu de ocupar, dominar e "gerir" as culturas recentemente descobertas, militarmente conquistadas e que estão sendo colonizadas? A partir do século XVII a 'segunda modernidade' não teve escrúpulos de consciência (Gewissen) com perguntas que já estavam respondidas de fato: desde Amsterdã, Londres o Paris (nos séculos XVII e XVIII em diante) o 'eurocentrismo' (superideologia que fundará a legitimidade da dominação do sistema-mundo) não será posto em questão nunca mais, até o final do século XX -- e isto, entre outros movimentos, pela filosofia da libertação. (DUSSEL, 2002, p.60).

O Filósofo nos lembra ainda a importância do ouro e da prata encontrados na América espanhola para a vitória cristã na batalha de Lepanto, quando a "Liga Santa" formada pela República de Veneza, Reino de Espanha, Cavaleiros de Malta e Estados Pontifícios sob o comando de João da Áustria, venceram o Império Otomano no dia 7 de outubro de 1571, no largo de Lepanto, na Grécia, em uma batalha que representou o fim da expansão islâmica no Mediterrâneo. Esta vitória, segundo Dussel, só foi possível porque vinte cinco anos antes foram descobertas e exploradas as minas de Zacatecas, no México e de Potosí na Espanha, o que permitiu a Espanha investir em armas e desequilibrar a correlação de forças naquela região de fronteira ${ }^{5}$.

Mas voltando ao ano de 1550 e ao episódio da Controvérsia de Valladolid, constatamos que a primeira estratégia de Las Casas - já que não

\footnotetext{
5"Foi a América que deu a Europa essa vantagem comparativa, que se explica em parte sobre o mundo muçulmano vencido em Lepanto em 1571 (25 anos após terem sido descobertas e terem começado a ser exploradas as minas de Zacatecas, no México, e de Potosí, na Bolívia). DUSSEL, 2002, p.90.
} 
poderia simplesmente ir contra Aristóteles, foi partir para problematização acerca de quais os sentidos de barbárie na obra do Estagirita ${ }^{6}$. Neste sentido, Las Casas defende que os índios eram capazes de se governar a si mesmos, não precisando então ser governados por outros. Eles também seriam capazes de ser instruídos pacificamente na fé católica e iniciados nos sacramentos, por isso a guerra nunca devia ser usada para esse fim, só a persuasão (Cf. De unico vocationis modo [LAS CASAS,1537]).

Las Casas afastou-se assim da doutrina sobre a escravidão prevista na Política e não deixou de ressaltar que Aristóteles era um desconhecedor da verdade e caridade cristã. E neste ponto da argumentação passou a se utilizar de questões centrais desta doutrina, como o amor ao próximo e princípio de caridade, enquanto marcos teóricos mais profundos aos quais se deveria voltar o cristianismo no trato com os nativos: "nisto desaprovamos Aristóteles, pois de Cristo, que é verdade eterna, temos o seguinte mandato: 'Amarás a teu próximo como a ti mesmo' (Mateus, 22); e também o apóstolo Paulo diz (Epístola aos Coríntios, 13): 'A caridade não procura o que é seu, porém o que é de Jesus Cristo” (LAS CASAS, in GUTIÉRREZ, 2014, p. 229).

É importante ainda ressaltar que no ano de 1537 foi publicada a Bula do Papa Paulo III, declarando que os índios eram 'verdadeiros homens' e que, portanto, possuíam alma (LAS CASAS, 1984, p. 21). Ou seja, pelo menos em teoria não tardou tanto o reconhecimento de que aqueles bípedes emplumados que habitavam as terras do Novo Mundo eram tão humanos quanto os europeus. Mas a formulação de Las Casas que realmente marcou época referente a este período e a esta questão ameríndia, foi a seguinte:

Todas as nações do mundo são homens, e de cada um deles só pode ser uma a definição: todos têm entendimento e vontade, todos têm cinco sentidos exteriores e quatro interiores, e se movimentam por meio deles, todos se alegram com o bem e sentem prazer com o saboroso e alegre, e todos rejeitam e aborrecem o mal e se alteram com o sem-sabor e lhes faz dano (LAS CASAS, in GUTIÉRREZ, 2014, p. 231).

Esta discussão e este trecho enquanto sua formulação final marcam a história dos direitos humanos no planeta, e não à toa, os ameríndios foram seus protagonistas. De fato, o impacto da descoberta, invasão e conquista da América mexeu com toda a intelectualidade europeia, e particularmente neste tema sensível que era o princípio de igualdade política entre os homens. Reverberações explícitas estão presentes, por exemplo, no que Oswald de Andrade chamou de ciclo das Utopias (A Utopia de Morus é de

\footnotetext{
6 "bárbaros no sentido próprio e estrito do termo, e os do livro terceiro, que, embora não fossem letrados, tinham governos legítimos, justos e naturais, Las Casas concluiu: "Nem todos os bárbaros carecem de razão nem são servos por natureza ou indignos de se governar a si próprios" (GUTIÈRREZ, 2014, p. 229).
} 
1516, por exemplo), e também nas obras de Montaigne e Rousseau que tanto vão influenciar o ideário da revolução Francesa. É a partir destas reflexões que Oswald de Andrade irá afirmar, não sem ironia que: "sem nós a Europa não teria sequer a sua pobre declaração dos direitos do homem" (ANDRADE, 1978, p. 14).

O que eles não sabiam, e nem Oswald poderia suspeitar, é que este conceito de humanidade não se aplica facilmente, ou sem violência, aos ameríndios. Porque contraposta a toda arrogância implícita, por exemplo, no compromisso com a universalidade assumido pela Filosofia ocidental, os nativos ameríndios se reservam o direito de serem humanos outros, de utilizarem seus recursos fisiológicos mais ou menos padronizados pela evolução biológica da espécie, para outros fins, a partir de outras prioridades sociais, políticas e espirituais.

Mas o fato é que se a pauta histórica dos direitos humanos não contempla completamente o horizonte da vida dos ameríndios, a ela estamos atados como náufragos no oceano das injustiças históricas, apegando-nos assim a alguns marcos jurídicos nacionais e internacionais que sobre ela incidem. Neste sentido, o que aconteceu a 500 anos atrás e continua a ocorrer hoje configura-se como sendo o eterno retorno do encontro (a partir da brilhante formulação do pensador e liderança indígena Ailton Krenak); ou do mau-encontro, como o propõe Pierre Clastres, propondo que este encontro se dá fundamentalmente com a estrutura hierarquizada do Estado etnocida.

\section{Do etnocídio}

Pierre Clastres, no texto intitulado Do etnocídio, se propõe justamente a responder a esta questão: se toda cultura é etnocênctrica, no sentido de que cada uma delas se propõe enquanto parâmetro de humanidade a partir do qual toda a diferença é minoritária ${ }^{7}$, por que só o Estado é etnocida?

A resposta a esta questão também remonta, nos marcos da história da filosofia Ocidental, a Aristóteles. O texto base desta vez é a Metafísica, mais especificamente o Livro $\mathrm{X}$, onde se estabelece a ideia de que o Um, enquanto supremo Bem, se manifesta no mundo imanente como ordem (taxis. Cf. AGAMBEN, 2011, p. 58). Neste sentido, a ordem é algo que se impõe ao mundo a partir de um princípio político de governança. ${ }^{8}$ Esta formulação da ordem enquanto exercício do poder de um sobre muitos remonta na história do Ocidente a Homero: "mas os entes não querem ser mal governados. Não é bom o mando de muitos, um só deve exercer o mando" ([Ilíada, II, V, 204], in ARISTÓTELES, 1998, 1076a).

\footnotetext{
${ }^{7}$ E desta constatação os ameríndios não são uma exceção. Cf. P Clastres, 2004, p. 58.

${ }^{8}$ Sobre a formação deste conceito e seus desdobramento políticos dentro da temática do pensamento ameríndio, Cf. Revista Clareira, Fontes, 2015, p. 166.
} 
Eis então a formulação política clássica de concepção do poder como aquilo que é capaz de impor a ordem:

\begin{abstract}
devemos examinar em qual dos dois modos a natureza do universo possui o bem e o ótimo, se como algo separado [kechōrismenon] e por si mesmo [kath' hauto] ou como uma ordem [taxin] Ou então de ambos os modos, como [acontece em] um exército. $\mathrm{O}$ bem consiste aqui, de fato, na ordem, mas é também o comandante, ou antes é sobretudo este. O comandante não existe, de fato, por causa da ordem, mas a ordem por causa do comandante Todas as coisas estão de fato ordenadas tendo em vista o uno, mas como, em uma casa [en oikiai], aos homens livres cabe uma menor faculdade de comportar-se sem pensar, e todas ou a maioria [de suas ações] são ordenadas, enquanto nos escravos e nos animais pouco se faz pelo comum e eles agem em geral ao acaso. O princípio que os dirige [arché] é, para cada um, sua natureza (ARISTÓTELES, 2002, 1075a).
\end{abstract}

Ou seja, a partir de Aristóteles, para haver ordem, para haver política, é preciso que um exerça o poder. A esta formulação está implícita outra, que vem a ser: a natureza do poder é a imposição de uma ordem centralizada, logo, a atitude essencial do exercício do poder é a coerção para aceitação desta centralidade da ordem. E é para isso que deve existir a coerção, ou melhor, é neste sentido que a coerção é legitimada. Segundo nossa leitura, estes princípios constituíram os Estados.

No entanto, é natural que se pergunte, mas e os Estado não ocidentais, como ficam neste quadro teórico? E as civilizações americanas que tinham Estados, como a Inca, para ficarmos circunscritos à América do Sul?

Bem, de fato os Incas tinham não apenas um Estado, mas um Império e uma estrutura de hierarquia rigorosa: obrigavam os povos submetidos a seu poder a pagar tributos em forma de horas de trabalho e a colocar a divindade oficial do Império, o Inca (deus sol) em primeiro plano em seus templos, acima de todas as outras ${ }^{9}$. Mas é importante pontuar que apesar do imperialismo, o Estado Inca não era etnocida, no sentido de que para se impor precisasse aniquilar toda a diferença dentro de seus domínios. Como prova disso foi a existência de uma ilha de resistência cultural bem próxima a capital do Império, os Aymara.

Mas o centro de nossa investigação está de fato nas populações humanas sem Estado, as quais integram o que convencionou-se chamar na literatura antropológica de as terras baixas da América do Sul, e sua relação com esta disposição intrinsecamente etnocida das Políticas de Estado, tanto do ponto de vista histórico como contemporâneo. Segundo P. Clastres a violência etnocida enquanto negação da diferença, pertence claramente à

${ }^{9}$ Cf. A sombra do Inca, Fausto, 2010, p. 15. 
essência do Estado, tanto nos impérios bárbaros quanto nas sociedades civilizadas do Ocidente: "toda organização estatal é etnocida, o etnocídio é o modo normal de existência do Estado" (CLASTRES, 2004, p. 61). Tratase então diretamente da questão da imposição da unificação, o poder simbolizado no Estado como sendo a imposição de uma ordem política centralizada. É neste contexto, por exemplo, que se encontra o princípio de soberania tão caro a Carl Schidmitt, cuja teoria, inclusive, pensa o exercício da soberania do Estado a partir da dialética amigo-inimigo. Onde o inimigo, a diferença, precisa ser aniquilado. Segundo Clastres, "descobre-se assim, no núcleo mesmo da substância do Estado, a força atuante do Um, a vocação da recusa do múltiplo, o temor e o horror da diferença" (CLASTRES, 2004, p. 87).

\title{
Marcos legais entre os índios do Brasil
}

Neste sentido, ao propormos nos debruçar sobre o pensamento ameríndio, entendemos que seria interessante (quiçá incontornável) passar pela problematização de como o Estado brasileiro, e antes dele a Coroa Portuguesa, vem lidando com a presença desta alteridade a disputar-lhe o território.

Neste sentido, o primeiro etnocídio enquanto política sistemática do Estado se deu através da obsessiva propagação da fé cristã, e a não menos fanática definição das práticas ritualísticas ameríndias como coisa de satã, ou seja, supôs-se que a cultura espiritual dos povos ameríndios tinha ligações diretas com o inimigo de Deus (satã ou lúcifer), e por isso precisava a todo custo ser suprimida, aniquilada. Os relatos dos primeiros padres e cronistas dão conta das dificuldades e saias justas geradas pela tentativa reiteradas de conversão ${ }^{10}$.

Renato Stutzman, em seu clássico O profeta e principal (2002), faz uma análise bastante interessante desta questão, acerca dos paradoxos vividos pelos cristãos ao se depararem com as crenças e práticas no Novo Mundo:

\begin{abstract}
As fontes quinhentistas e seiscentistas - boa parte delas produzida por missionários cristãos, outras produzidas por homens impregnados por valores religiosos - possuem uma etnografia incipiente fortemente marcada por valores conflitantes que apontam um mundo em transformação: a cosmologia cristã medieval era aos poucos revista e alterada por ideais humanistas e por uma política secularizada, que tentava delimitar o campo de ação do Estado (STUTZMAN, 2002, p.137).
\end{abstract}

${ }^{10}$ Cf. LÉRY, 1980, p. 112-196-204-207; STADEN, 1974, p. 96-100-112. 
Jean de Léry e André Thevet, por exemplo, nos dão vários testemunhos deste conflito moral entre as práticas culturais do velho mundo e essa novidade humana recém encontrada. Isto porque neste período também os Estados europeus nascentes encontravam-se imersos em encaniçado conflito civil conhecido como guerras religiosas, em que o catolicismo e o protestantismo lutavam pela hegemonia dentro do aparato político de poder que era o Estado ${ }^{11}$.

Fato é que já tínhamos de fato um Estado na América do Sul, o Inca, mas o qual por razões diversas, não teve penetração relevante na região denominada de terras baixas da América do Sul. Segundo P. Clastres isto teria se dado em parte por questões geográficas e de relevo, a mata atlântica sendo completamente diferente dos planos, vales e altiplanos pelos quais se espalhou o Império; mas talvez sobretudo pela rebeldia ou indocilidade dos povos ameríndios e sua completa rejeição ao modelo de centralismo cultural e político proposto pelo Império. É que os nativos ameríndios não reconheciam autoridade exterior. Nem interior, no sentido do poder como coerção, já que sua organização política era amplamente marcada pelo formato de conselhos, pela ausência da relação de mando-obediência e pela dinâmica onipresente da guerra ininterrupta ${ }^{12}$.

Já os europeus que chegaram pela Costa Atlântica e ficaram abismados com a fauna e a flora aqui presentes, em tudo desconhecida deles, estavam política, econômica e ontologicamente (no que diz respeito ao impulso metafísico oriundo da fé cristã) compromissados com a conquista. No entanto, como vimos anteriormente, pelo menos da parte dos Estados Ibéricos (Portugal e França) houve escrúpulos de consciência e a necessidade de um novo arranjo jurídico para dar conta dos direitos e deveres desta nova humanidade recém encontrada. A primeira instituição jurídica utilizada pela Coroa Espanhola para disciplinar a utilização da mão de obra nativa e a ocupação das terras do Novo Mundo vinha do século V d.C, e era chama chamada de encomienda. Esta estrutura foi utilizada originalmente no ocidente pelos romanos, como estratégia para se apropriar das terras conquistadas pelo Império, à qual passavam então a gerir em troca de proteção militar. Era o início do modelo de servidão que irá marcar toda a Idade Média.

No que se refere à Conquista da Nova Espanha, os nativos eram então submetidos ao trabalho forçado, mas teriam em tese direito à remuneração como homens livres submetidos a Coroa e não poderiam sofrer maus tratos. Claro que a distância entre a teoria jurídica e a prática empírica

\footnotetext{
${ }^{11}$ Inclusive a famosa empreitada de Villegagnon de implantação na Baía de Guanabara de uma França Antártica está mais diretamente ligada a essa questão das guerras religiosas do que de um empreendimento econômico mercantil. Cf. Léry, 1980, p. 53,54-57.

12 “a guerra é ao mesmo tempo a causa e o meio de um efeito e um fim buscados, a fragmentação da sociedade primitiva. (...) Em outras palavras, a guerra primitiva é o meio de um fim político." CLASTRES, 2004, p.172-173.
} 
é enorme, mas fato é que esta foi uma primeira solução encontrada na jurisprudência católica-romana para o projeto colonizador espanhol.

Com relação aos portugueses, a legislação sobre o estatuto jurídico e ontológico dos povos nativos encontrava-se em constante litígio e é marcada por exceções. Primeiro porque dois interesses se mantiveram em constante conflito com relação à tutela dos nativos: os colonos (desbravadores e bandeirantes) de um lado e os jesuítas do outro. O que estava em jogo era o modelo de captação da mão de obra, se por capturas ou descimentos e o destino dos trabalhos realizados por eles. Neste momento, a Coroa Portuguesa precisou conciliar os mandamentos da religião católica: não injuriar, nem prender e nem ferir os nativos até então tidos como inocentes de sua barbárie porque não conheciam as leis de Deus, e os interesses mundanos ou pragmáticos dos colonizadores e das finanças do Estado.

Segundo Perrone-Moisés, em influente artigo acerca das questões jurídicas implementadas pela Corte portuguesa quanto ao trato com os nativos: "os gentios cuja conversão justificava a própria presença europeia na América eram a mão-de-obra sem a qual não se podia cultivar a terra, defendê-la de ataques de inimigos tanto europeus quanto indígenas, enfim, sem a qual o projeto colonial era inviável" (PERRONE-MOISĖS, 1992, p. 116).

E um dado que faz tributo à diversidade presente entre as populações ocupantes das terras baixas da América do Sul é o fato de a Coroa ter proposto instrumentos legais (decretos e cartas régias) referentes a questões bastante específicas relativas a contextos locais, a partir de como se dava a relação entre os invasores e as etnias de cada região.

Vigorava, sempre em teoria, sobretudo o princípio de respeito da vontade livre dos nativos: os que não fossem assim convencidos [de deixar suas terras, aldeias e costumes] não deveriam em hipótese alguma ser forçados a descer, como dito expressamente na Lei de 10/9/1611 e no Regimento das Missões, de 21/12/1686. Ainda segundo a autora, a ilegalidade da coação ao descimento continuou sendo afirmada até o século XVIII ${ }^{13}$.

Mas um instrumento jurídico de escravização legal esteve sempre em pauta, que era o reconhecimento da necessidade de se estabelecer a guerra justa contra determinadas aldeias e etnias. Neste sentido, a guerra justa, mesmo sendo um conceito já antigo, foi motivo de muita discussão a partir do século XVI. Entre as causas legítimas de guerra justa estavam "à recusa à conversão ou o impedimento da propagação da Fé, a prática de hostilidades contra Vassalos e aliados dos portugueses (especialmente a Violência contra pregadores, ligada à primeira causa) e a quebra de pactos celebrados" (PERRONE-MOISÈS, 1992, p. 123).

\footnotetext{
${ }^{13}$ PERRONE-MOISÈS, 1992, p.118.
} 
Neste sentido a jurisprudência da Coroa portuguesa dá testemunho destes conflitos e dos interesses nele envolvidos, sendo a guerra justa uma questão particularmente delicada porque contrariava preceitos religiosos importantes previstos no que mencionamos acima acerca do aspecto salvacionista intrínseco ao impulso expansionista ibérico. Mas mesmo entre clérigos, tivemos figuras como Anchieta e Nóbrega as quais defendiam a guerra e a sujeição como único meio de converter os indígenas, ao mesmo tempo que colonizadores como Tomé de Souza consideravam a violência como prejudicial a conversão. Como conclusão têm se que: "sendo a guerra justa possibilidade indiscutível de escravização lícita, pode-se imaginar o interesse que sua declaração tinha para os colonizadores" (PERRONEMOISÈS, 1992, p. 124).

Trazendo agora um dado que toca mais de perto uma questão até hoje candente que é a relativa ao reconhecimento do direito de posse das terras pelos nativos, temos que as terras das aldeias eram garantidas aos índios desde o início das relações com os nativos, sobretudo a partir da expressão "senhores das terras das aldeias, como o são na serra". O que quer dizer que mesmo as terras dos aldeamentos próximas aos povoados Portugueses para a quais eram direcionados os índios descidos, eram reconhecidas como sendo de sua posse ${ }^{14}$.

\section{Indigenato e a Tese do Marco temporal.}

Atualmente, no que tange a situação jurídica dos indígenas brasileiros, sobretudo no que diz respeito à posse e soberania sobre suas terras, o conflito permanece sujeito a dois princípios legais, sendo um deles francamente incoerente, ou que só é passível de fazer sentido se aceitarmos que os mais recentes marcos regulatórios do Estado brasileiro reinauguram o conceito de guerra justa a partir de um projeto de Lei que pretende anistiar (esquecer) todos os crimes perpetrados contra indígenas, sobretudo no que se refere a tomada de suas terras, ocorridos antes de 1988. Trata-se da tese do Marco Temporal.

Sobre esse assunto podemos dizer que a Constituição de 1988 previa o fim do etnocídio enquanto prática do Estado brasileiro, e buscava dar fim a tese do assimilacionismo que vigorava desde Pombal, e que ainda se encontrava presente, por exemplo, no estatuto do índio de 1979.

De maneira bastante condensada, podemos dizer que a tese assimilacionista é aquela que entende que os nativos estariam em um estágio inferior de evolução cultural da humanidade, e que por isso a tendência

\footnotetext{
${ }^{14}$ Declaração dessa garantia, aparece pela primeira vez no Alvará de 26/7/1596 e será retomada nas Leis de 1609 e 1611. Várias Provisões tratam da demarcação (presente desde o Alvará de 26/7/1596) e garantia de posse dessas terras (p. ex.: Provisão de 8/7/1604, Carta Régia de 17/1/1691, Diretório de 1757, pars. 19, 80). (PERRONE-MOISÈS, 1992, p.119).
} 
natural dos povos nativos, conforme fossem evoluindo a partir do contato espontâneos ou forçado com o mundo dos brancos, era a de se integrar as práticas e costumes da sociedade nacional e irreversivelmente deixar a floresta.

Nos marcos dessa discussão, a primeira ferramenta jurídica utilizada para regulamentar a situação dos índios foi o indigenato, conceito que inaugura o reconhecimento legal dos nativos sobre suas terras, e que tem sua primeira formulação na Carta Régia de 30/07/1611, Promulgada por Felipe III: "os gentios são senhores de suas fazendas nas povoações, como o são na serra, sem lhes poderem ser tomadas, nem sobre elas se lhes fazer moléstia ou injustiça alguma; nem poderão ser mudados contra suas vontades das capitanias e lugares que lhes forem ordenados, salvo quando eles livremente o quiserem fazer" (SILVA, 2016, p. 9).

Anos depois tivemos o Alvára de $1^{\circ}$ de abril de 1680 que de fato institui o indigenato enquanto figura jurídica. E em seguida a Lei de 06/06/1775: que reconhece os índios como primários e naturais senhoras das terras por eles ocupadas (SILVA, 2016, p. 4). Agora, se o que se pretende é pensar esta relação nos marcos do Estado brasileiro como atualmente vigente, ou seja, desde a sua constituição enquanto República. O marco temporal reativos aos direitos dos índios sobre a posse de suas terras milenarmente ocupadas deveria ser, no mínimo, a Constituição de 1934, que em seu artigo 129: reconhece a posse a partir da permanente ocupação e veda a alienação, ou seja, a venda destas terras a terceiros: "será respeitada a posse de terras de silvícolas que nelas se achem permanente localizados, sendo-lhes, no entanto, vedado aliená-las" (SILVA, 2016, p. 4).

Segundo o parecer do professor José Afonso da Silva, professor titular aposentado da faculdade de Direito da USP: é aqui que temos inequivocamente um marco temporal. O reconhecimento dos direitos originários dos índios sobre as terras que ocupam. Quando, "se dá àqueles direitos uma nova configuração jurídico-formal, retirando-os das vias puramente ordinárias para consagrá-los como direitos fundamentais dotados de supremacia constitucional [...] demais Constituições dão continuidade a essa consagração até à Constituição de 1988, que acrescentou outros direitos" (SILVA, 2016, p. 9).

Na Constituição de 1988, chamada Constituição cidadã, deu-se um grande passo no sentido do reconhecimento dos direitos dos povos originários sobre suas terras e o reconhecimento do exercício de sua cidadania diferenciada. Pode-se até dizer que este texto documenta uma tentativa do Estado brasileiro de deixar de ser etnocida, quando se dispõe a reconhecer "aos índios sua organização social, costumes, línguas, crenças e tradições, e os direitos originários sobre as terras que tradicionalmente ocupam, competindo à União demarcá-las, proteger e fazer respeitar todos os seus bens" (Constituição brasileira de 1988, art. 231). 
E nesse âmbito, já que estamos tratando especificamente do direito à posse indígena sobre estas terras, seria interessante dar ênfase ao parágrafo $1^{\mathrm{o}}: \S 1^{o}$ - "São terras tradicionalmente ocupadas pelos índios as por eles habitadas em caráter permanente, as utilizadas para suas atividades produtivas, as imprescindíveis à preservação dos recursos ambientais necessários a seu bem-estar e as necessárias a sua reprodução física e cultural, segundo seus usos, costumes e tradições" (Constituição brasileira de 1988 , art. $231^{15}$ ).

No marcos desta Jurisprudência é interessante pontuar que o processo de demarcação da Terra Indígena Raposa Serra do Sol, homologada em 2005, representou para a causa indígena uma vitória de Pirro, pois a partir deste processo foram levantadas pela Suprema Corte brasileira duas teses particularmente problemáticas as quais na prática funcionam como instrumentos de retirada de direitos indígenas. Sãos elas: a tese do Marco temporal da ocupação, a qual busca implementar, a partir do referido processo, a data de promulgação da Constituição (ou seja, 5 de Outubro de 1988) como marco temporal para a ocupação das terras indígenas sobre litigioso processo demarcatório, ou seja, todas as aldeias e etnias que não estavam sobre suas terras neste momento de promulgação do texto Constitucional, deixam de ter direito sobre estas terras. Trata-se na prática, de uma escandalosa anistia de todas as violências cometidas por entes privados ou agentes do Estado que resultaram na expulsão das populações nativas de suas terras originárias efetuadas antes dessa data.

E a segunda tese, a primeira vinculada, estipula o inacreditável critério de renitente esbulho como elemento fundamental para o reconhecimento da luta dos povos originários pela ocupação destas terras. Acrescente-se que no texto da Constituição que encontramos na pagina oficial do STF, no qual constam todos os comentários a partir das decisões mais recentes tomadas pela suprema Corte, encontramos a seguinte explicação acerca de como deve ser entendido o renitente esbulho:

Renitente esbulho não pode ser confundido com ocupação passada ou com desocupação forçada, ocorrida no passado. Há de haver, para configuração de esbulho, situação de efetivo conflito possessório que, mesmo iniciado no passado, ainda persista até o marco demarcatório temporal atual (vale dizer, a data da promulgação da Constituição de 1988), conflito que se materializa por circunstâncias de fato ou, pelo menos, por uma controvérsia possessória judicializada (Conforme entendimento da Súmula $\left.650 / \mathrm{STF}^{16}\right)$.

Não à toa essa disposição da Suprema Corte causa espécie ao professor Constitucionalista José Afonso da Silva, pois este entende que

\footnotetext{
${ }^{15}$ Disponível em: http://www.planalto.gov.br/ccivil_03/constituicao/constituicao.htm.

${ }^{16}{ }^{16}$ Disponível em: http://www.stf.jus.br/portal/constituicao/artigobd.asp?item=\%202051.
} 
estas da tese do Marco Temporal, somada ao critério de Renitente Esbulho, configuram-se enquanto flagrantes atentados aos direitos indígenas como previstos pela carta magna do país. E o mesmo professor apresenta em seu parecer ${ }^{17}$ dados do relatórios da Comissão Nacional da Verdade, como por exemplo os contidos no relatório Figueiredo, os quais dão inegável testemunho da destituição e retirada forçada dos índios de suas terras. Além disso, o renomado professor se pergunta como o renitente esbulho - que para se configurar necessita, além das circunstâncias de fato (solapadas pela tese do Marco temporal) de uma controvérsia possessória judicializada; como os indígenas poderiam judicializar a lutas por suas terras se somente a partir do art. 232 da mesma Constituição de 1988 é que foi conferido aos povos nativos, suas comunidades e organizações, legitimidade para ingressar em juízo em defesa de seus direitos e interesses, contando a partir daí com a intervenção constitucional do Ministério Público em todos os atos do processo.

Mas antes mesmo da Constituição, já poderíamos assinalar que um ponto importante relativo à postura do Estado brasileiro referente à questão indígena está presente a partir do lugar ocupado pelos órgãos responsáveis pela questão indígena dentro da burocracia estatal. Esta questão, que poderia ser tratada como meramente residual, apresenta amplas implicações quanto às questões práticas de ativação do reconhecimento e pleno exercício dos direitos indígenas por parte do Estado brasileiro. E ela diz respeito à subordinação dos órgãos tutores dos índios - SPI e FUNAI, às políticas governamentais:

A subordinação do órgão tutor dos índios, encarregado de defender seus direitos, em relação às políticas governamentais fica evidente quando se nota que o Serviço de Proteção aos Índios (SPI) era órgão do Ministério da Agricultura e que a Fundação Nacional do Índio (Funai), que substituiu o SPI em 1967, foi criada como órgão do Ministério do Interior, o mesmo ministério a cargo do qual estavam a abertura de estradas e a política desenvolvimentista em geral. Acrescentese a esse quadro a anomalia jurídica de não haver um órgão curador a quem o órgão tutor dos índios devesse prestar contas de suas ações. Assim, é estrutural o fato de os órgãos governamentais explicitamente encarregados da proteção aos índios, o SPI e posteriormente a Funai, não desempenharem suas funções e se submeterem ou até se colocarem a serviço de políticas estatais, quando não de interesses de grupos

\footnotetext{
17 Parecer elaborado a pedido de Manuela Carneiro da Cunha, do Centro de Trabalho Indigenista, do Instituto Socioambiental, entre outros. Disponível em: http://www.mpf.mp.br/atuacao-tematica/ccr6/documentos-e-

publicacoes/artigos/docs_artigos/jose-afonso-da-silva-parecer-maio-2016-1.pdf.
} 
particulares e de seus próprios dirigentes. (KEHL, 2014, p. $199)^{18}$.

A partir desta colocação fica mais fácil entender os absurdos práticos e jurídicos que tornaram a Usina de Belo Monte possível. O etnocídio das aldeias naquele perímetro foi feito em nome dos interesses estratégicos do Estado. Ou seja, em nome da pauta de um desenvolvimentismo projetado pelos militares, requentado e colocado no forno em plena democracia, e de maneira não mesmo escandalosa, por um dos partidos mais representativos das pautas dos direitos humanos, identificado em termos políticos com o que tem se chamado de esquerda brasileira.

\section{Conclusão}

Para concluir, entendemos que se algo unifica os mundos ameríndios e o nosso, imersos que estamos na lógica do capitalismo global, não é a Ciência enquanto narrativa epistêmica hegemônica que se tornou o que é através de diversas crises e interesses, pois "o mundo sintético da ciência é um mundo da coerência remendada" (WAGNER, 2012,p. 355).

O que unifica então de fato nossos mundos são as lutas, políticas, cosmopolíticas e seus vetores de opressão, aniquilação ou resistência. É neste horizonte de conflitos que os mundos índio e não-índio de fato se encontram. E entendendo que o modelo político de poder do Estado se tornou hegemônico, essas lutas, mesmo que mobilizando mundos diferentes (e suas respectivas cosmopolíticas), estão imersos em uma mesma jurisprudência, que se configura a partir de determinados marcos nacionais e internacionais.

Mas os Estados nacionais estão por sua vez subordinados a uma lógica que lhe subjaz, que é a lógica globalizada da produção capitalista. Esta conjunção é que é de fato a ameaça mais radical e total a vida e a existência dos mundos ameríndios. Neste sentido, vê-se o Estado brasileiro, ao propor uma indenização em dinheiro aos povos ameríndios expropriados de suas terras, reeditar a lógica malsã a partir da qual tudo acaba em dinheiro. Segundo Stengers, se:

produce la idea indigna de que una compensación financiera tendría que bastar, el intento obsceno de dividir a las víctimas, de aislar a los que son reacios y abordar primero a los que, por una u otra razón, aceptan plegarse más fácilmente. Quizá todo termina con dinero, pero no "debido" al dinero, porque el dinero no cierra la cuenta. Los que se reúnen tienen que saber

\footnotetext{
${ }^{18}$ Comissão Nacional da Verdade, relatório final, texto 5, Violações dos Direitos humanos dos povos indígenas. Atualmente a FUNAI encontra-se subordinada ao Ministério da Justiça, cujo atual ministro, Osmar Serraglio, é reconhecido pela sua atuação parlamentar diretamente ligada ao agronegócio.
} 
que nada podrá borrar la deuda que vincula su eventual decisión con sus víctimas (2014, p.39).

Sendo assim, temos que o maior inimigo da diversidade humana, aqui representada pelos povos ameríndios, e do direito de habitarem de maneira ontologicamente auto-determinada seus mundos, é o Estado Capitalista. Este configurando-se como um típico híbrido (ou a hybris típica) da modernidade, se pensarmos nas considerações de Latour acerca da Constituição moderna. E esta não é uma questão meramente econômica, mas da política pensada em sua esfera mais profundo. Pierre Clastres mais uma vez, faz uma excelente exposição do que vem a ser o caráter etnocida do Estado capitalista, e porque ele representa a maior ameaça aos povos tradicionais, e quiçá, a permanência da vida humana na terra:

\begin{abstract}
O que a civilização ocidental contém que a torna infinitamente mais etnocida que qualquer outra forma de sociedade? É seu regime de produção econômica, espaço justamente do ilimitado, espaço sem lugares por ser recuo constante do limite, espaço infinito da fuga permanente para diante. $O$ que diferencia o Ocidente é o capitalismo, enquanto impossibilidade de permanecer no aquém de uma fronteira, enquanto passagem para além de toda fronteira; é o capitalismo como sistema de produção para o qual nada é impossível, exceto não ser para si mesmo seu próprio fim: seja ele, aliás, liberal, privado, como na Europa ocidental, ou planificado, de Estado, como na Europa oriental. A sociedade industrial, a mais formidável máquina de produzir, é por isso mesmo a mais terrível máquina de destruir. Raças, sociedades, indivíduos; espaço, natureza, mares, florestas, subsolo: tudo é útil, tudo deve ser utilizado, tudo deve ser produtivo; de uma produtividade levada a seu regime máximo de intensidade. (CLASTRES, 2004, p. 62).
\end{abstract}

Neste sentido, entendo que investigar a questão ameríndia, suprimindo ou menosprezando a questão política é de uma violência igual a cometidas por madeireiros ou garimpeiros. Afinal, como fica bem claro na narrativa autobirgráfica do pajé e líder Yanomami Davi Kopenawa, A Queda do Céu (2014), suas cosmologias herdadas só são passíveis de serem conhecidas a partir de um longo processo de iniciação que exige do aspirante, não apenas um convívio atento e diferenciado com a floresta, nem apenas a ingestão do pó yãkoana nos longos jejuns, mas também a presença de um mestre guia, entre outras nuances que me escapam completamente enquanto indivíduo urbano, cujo interesse e acesso a estes mundos se dá apenas através das peles de imagens onde estão desenhadas as palavras (KOPENAWA, 2016, p. 96-138,139) .

Me pergunto então sinceramente acerca da pertinência ou leviandade implícita (mesmo que involuntária) em um projeto que busca estabelecer as nuances filosóficas presentes em uma suposta tábua de categorias 
Yanomami, pois isto me parece ressoar a presunção da velha filosofia mesmo que em nova chave, a qual busca desbravar, sem sair do lugar, todos os mundos. Reverberando assim a mesma lógica investigativa que intentou, durante tanto tempo, definir o ser humano universal, só que agora em nova chave, a qual poderia ser chamada talvez de exotismo ontológico. Pois continuaríamos assim a ser, nós ocidentais, "os milionários em mundos, os acumuladores de mundos, os "configuradores de mundos'" (VIVEIROS DE CASTRO, 2010, p. 20).

Volto a afirmar, se alguma ponte é possível entre o nosso mundo, urbano, ocidental, acadêmico, e os diversos mundos ameríndios, essa ponte é política. Não a política com sentido fixo, muito menos algo parecido com nosso sistema representativo-partidário, mas que passa necessariamente pela pauta dos direitos humanos e pelo reconhecimento das limitações da tradição Filosófica ocidental quando em contato com outros mundos. Respeitar a imaginação conceitual ameríndia não nos exime de analisar a sua incontornável implicação política. E muito menos nos desobriga de problematizar esta relação, a partir da constatação que a Universidade (particularmente a pública) é instrumento de Estado, custeada pela mesma fonte de recursos que dão insumos ao agronegócio, por exemplo.

Para finalizar, trago aqui uma fala do pensador e liderança indígena Ailton Krenak, dita na ocasião do colóquio internacional Mil Nomes de Gaia, quando encerra sua fala dizendo: "eu, sinceramente, não entendo por que as pessoas querem adiar o fim do mundo [...] a gente podia pelo menos ter coragem de admitir o fim deste mundo e ver se nós somos capazes de aprender alguma coisa" (KRENAK, 2014). Penso então que um mergulho no pensamento ameríndio deve no mínimo buscar reverberar essa coragem de reconhecer que até aqui não estamos indo bem, e logo não faz sentido, se estamos verdadeiramente interessados na possibilidade de um outro mundo, continuarmos a fazer o que estamos fazendo, do mesmo jeito que viemos fazendo há pelo menos meio milênio.

Sendo assim, se a pauta dos Direitos humanos não alcança em sua inteireza as definições ameríndias de existência, o estatuto ontológico dos espíritos, dos animais, e dos outros que humanos; entendo que, partindo de onde estamos, ou seja, dentro da esfera de influência da jurisprudência do Estado Nacional e da dinâmica do capitalismo global, é esta pauta nossa ferramenta fundamental de contato (desde que, claro, não passemos a praticar etnologia e assim nos tornarmos capazes adentrar de fato aqueles mundos). O que quero dizer é que entendo que do lugar de onde estamos, enquanto ocidentais urbanizados, chegar ao tema dos ameríndios passa necessariamente pela questão política representada pelos Estados, a jurisprudência que os acompanha, e a dinâmica econômica que lhes subjaz. Isto mesmo se pensarmos no caso limite da autodemarcação das terras feitas pelos Mundurukú, na região do médio Tapajós. 
Afinal, se a Queda do Céu pode ser entendida como uma "crítica xamânica da economia política da natureza" (ALBERT, 1993), é forçosamente necessário, antes de realizar o salto metafísico de analisar as nuances do conceito de espectro na cosmologia Yanomami, por exemplo, problematizar de que forma esta economia política alcança os Yanomami. Seria muito mais frutífero, acredito, analisar as dimensões políticas e cosmopolíticas envolvidas no conceito de povo da mercadoria. Pensar por exemplo a relação entre o mercado mundial de minérios e a expansão da epidemia xawara. Neste sentido é muito interessante a proposição de um Marx selvagem (2013), feita pelo cientista político Jean Tible, ao pensar um paralelo entre as obras de P. Clastres e K. Marx, enquanto críticas à estrutura política do Estado, e das dinâmicas econômicas nas quais estas relações de poder estão imersas.

Por fim, estou convencido de que jamás se construirá ninguna memoria ni ninguna experiencia bajo el auspicio de una neutralidad metodológica (STENGERS, 2014, p. 27). O que não significa abandonar a ciência, muito menos a filosofia. Na verdade, talvez todo este texto não passe de um preâmbulo para uma entrada filosófica politicamente mais coerente no conteúdo mesmo do pensamento ameríndio, afim de melhor captar sua riqueza, potência política (cosmopolítica), nuances e implicações. 


\section{Referências bibliográficas}

AGANBEM, G. O reino e a glória : uma genealogia teológica da economia e do governo : homo sacer, II, 2 / Tradução Selvino J. Assmann. (Estado de sítio). São Paulo. Boitempo, 2011.

ALBERT, Bruce. "O ouro canibal e a queda do céu: uma crítica xamânica da economia política da natureza (yanomami)". In: B. Albert \& A. Ramos (orgs.), Pacificando o branco: cosmologias do contato norte-amazônico. São Paulo: Unesp. pp. 239-270, 2002.

ANDRADE, O. Do pau Brasil a antropofagia $e$ às utopias. Obras Completas. Rio de Janeiro: Civilização Brasileira, 1978.

ARISTÓTELES. A política. Traduzido por Roberto Leal Ferreira. São Paulo: Martins Fontes, 1998.

- Metafísica. Tradução de Giovanni Reale. Vol. II. São Paulo: Edições Loyola, 2002.

CLASTRES, P. A sociedade contra o Estado. São Paulo: Cosac\&Naif, 2013.

.A arqueologia da violência - pesquisas de antropologia política. São Paulo: Cosac\&Naif, 2004.

CLASTRES, H. Terra sem mal. $7^{\mathrm{a}}$ ed. São Paulo: Brasiliense, 1978.

RIBEIRO, DARCY. As américas e a civilização. Estudo de Antropologia da civilização. Rio de Janeiro. Ed. Vozes, 1977.

DUSSEL, E. Ética da libertação: na idade da globalização e da exclusão. Petrópolis: Vozes, 2002.

187-208, 1980.

Primitivismo e ciência do homem no Séc. XVIII. Discurso, 13:

FAUSTO, C. Os índios antes do Brasil. Ed. Jorge Zahar. $4^{\mathrm{a}}$ ed. Rio de Janeiro, 2010.

2002.

Banquete de gente. In Revista Mana vol. 8 n². Rio de Janeiro,

Cinco séculos de carne de vaca: antropofagia literal e literária.

Canibalismo e diferença. In Antropofagia hoje? (Orgs) RUFFINELLI, J.; ROCHA, J. C. C. São Paulo: É Realizações. pp. 161-170, 2011.

GUTIÉRREZ, J. L. A controvérsia de Valladolid (1550): Aristóteles, os índios e a guerra justa. In REVISTA USP. São Paulo. n. 101. p. 223-235, 2014.

KEHL, Maria Rita. Comissão Nacional da Verdade. Relatório final. Texto 5. Violações dos Direitos humanos dos povos indígenas, 2014.

KELLY, José. Resenha: La chute du ciel: paroles d'un chaman yanomami. Revista de Antropologia da UFSCar, v.5, n.1, jan.-jun, p.172-187, 2013.

KOPENAWA, D., ALBERT, B. A queda do céu. São Paulo. Companhia das Letras, 2016. 
Las Casas, Bartolomeu. Brevíssima relación de la destruición de las Indias ocidentales. Ou "O Paraíso Destruído". Ed. L\&PM Pocket. $2^{\mathrm{a}}$ ed. Porto Alegre - RS, 1984.

LATOUR, B. Jamais fomos modernos. Ensaio de antropologia simétrica. $2^{\text {a }}$ ed. São Paulo. Ed. 34, 1994.

Guerre des mondes - offres de paix. Article préparé pour un volume spécial de l'UNESCO, 2015.

Para distinguir amigos e inimigos no tempo do Antropoceno.

Revista de Antropologia, São Paulo, USP, v. 57 nº 1, 2014.

LÉRY, J. Viagem à terra do Brasil. $2^{\mathrm{a}}$ ed. Belo Horizonte: Ed. Itatiaia, 1980.

LÉVI-STRAUSS. Pensamento selvagem. Campinas-SP. Ed. Papirus, 2008.

MONTAIGNE, M. "Dos Canibais". In MONTAIGNE, M. Ensaios. São Paulo: Nova Cultural, 2004.

MUSSA, A. Meu destino é ser onça. $2^{\mathrm{a}}$ ed. Rio de Janeiro: Record, 2009.

NOCENTELLI-TRUET, C. Canibais devorados: Léry, Montaigne e identidades coletivas na França do século XVI. Canibalismo e diferença. Canibalismo e diferença. In (Orgs) RUFFINELLI, J.; ROCHA, J. C. C. Antropofagia hoje? São Paulo: É Realizações. pp.181-202, 2011.

PERRONE-MOISÈS, B. Índios livres e índios escravos: os princípios da legislação indigenista do período colonial (séculos XVI a XVIII). In História dos índios no Brasil, organização Manuela Carneiro da Cunha. São Paulo, Companhia das Letras, Secretaria Municipal de Cultura, FAPESP. pp. 115-132, 1992.

SILVA, José Afonso da. Parecer sobre o Marco Temporal. Registrado no Ministério Público Federal. Disponível em: http://www.mpf.mp.br/atuacaotematica/ccr6/documentos-epublicacoes/artigos/docs_artigos/jose-afonsoda-silva-parecer-maio-2016-1.pdf, 2016.

STADEN, Hans. Duas viagens ao Brasil. Ed. Itatiaia/Edusp. São Paulo, 1974.

STENGERZ, I. La propuesta cosmopolítica. Revista PLÉYADE. JulioDiciembre. pp. 17-41, 2014.

STUTZMAN, R. O profeta e o principal: ação política ameríndia e seus personagens. Edusp. São Paulo- SP, 2002.

TIBLE, Jean. A antropofagia de Marx, in Revista Nada, numero 18 p. 3051, 2014.

. Cosmologias contra o capitalismo: Karl Marx e Davi Kopenawa, in Revista de Antropologia da UFSCar, v.5, n.2, jul.-dez., p.46-55, 2013. . Marx selvagem. São Paulo: Editora Annablume, 2013.

Ribeiro, Darcy. As américas e a civilização: estudo de Antropologia da civilização. Ed. Vozes. Rio de Janeiro - RJ. 1977.

VIVEIROS CASTRO. E. A inconstância da alma selvagem e outros ensaios de antropologia. São Paulo: Cosac\&Naify, 2002. 
Araweté: os deuses canibais. $5^{\mathrm{a}}$ ed. Rio de Janeiro: Jorge Zahar, 1986.

Transformação da antropologia, transformação na antropologia; In Revista Mana, vol.18 nº 1 Rio de Janeiro, 2012.

. A propriedade do conceito. ANPOCS 2001 / ST 23: Uma notável reviravolta: antropologia (brasileira) e filosofia (indígena), 2001.

WAGNER, R. A invenção da cultura. Tradução: Marcela Coelho de Souza e Alexandre Morales. São Paulo. Cosac\&Naify, 2012.

Autor(a) para correspondência: Gustavo Fontes, Universidade Federal do Paraná, Faculdade de Filosofia, ciências e Letras, R. Gen. Carneiro, 460, Centro CEP 80060-150, Curitiba - PR, Brasil. fontesholanda@gmail.com 